Jurnal Teknologi, 41(A) Dis. 2004: 29-42

(C) Universiti Teknologi Malaysia

\title{
KEUTUHAN PERMUKAAN BAHAN KELULI PERKAKAS SETELAH PENGISARAN HUJUNG MENGGUNAKAN PERKAKAS KARBIDA BERSALUT
}

\author{
CHE HASSAN CHE HARON ${ }^{1}$, ANDANASTUTI MUCHTAR \& \\ NIK FAIZU NIK KUNDOR
}

\begin{abstract}
Abstrak. Projek ini dijalankan bertujuan untuk mengkaji kesan proses pengisaran terhadap keutuhan permukaan keluli perkakas D2. Dalam kajian ini, keluli perkakas kerja sejuk AISI D2 yang telah dikeraskan kepada 62 HRC dimesin menggunakan sisip karbida bersalut CVD boleh indeks yang dipegang oleh perkakas pengisaran hujung berdiameter $20 \mathrm{~mm}$. Siri-siri ujian dijalankan dalam keadaan kering. Penilaian ke atas permukaan yang dimesin melibatkan kekasaran permukaan dan analisis mikrostruktur. Keputusan kajian menunjukkan bahawa tiada hubungan yang jelas di antara variasi kelajuan pemotongan dan suapan terhadap kekasaran permukaan. Umumnya, permukaan yang dihasilkan adalah sangat licin dengan nilai $R_{a}$ berada dalam julat $0.10 \mu \mathrm{m}-0.43$ $\mu \mathrm{m}$ dan analisis permukaan pada sampel-sampel ujikaji juga mendapati hampir tiada perubahan dapat dikesan pada mikrostruktur bahagian bawah permukaan yang dimesin. Walau bagaimanapun, pada kelajuan pemotongan tertinggi $(160 \mathrm{~m} / \mathrm{min})$ dan suapan yang tinggi $(0.02 \mathrm{~mm} / \mathrm{sisip})$, terdapat kesan termampat dan terherot pada mikrostruktur pada kedalaman yang sangat cetek iaitu lebih kurang $2.2 \mu \mathrm{m}$ dari permukaan termesin.
\end{abstract}

Kata kunci: Keutuhan permukaan, keluli perkakas terkeras, pengisaran hujung, mikrostruktur, perkakas karbida bersalut

Abstract. The effect of milling process on the surface integrity of newly machined surface of D2 tool steel is presented. The hardened AISI D2 (62 HRC) was machined under dry cutting conditions using a $20 \mathrm{~mm}$ diameter end-milling tool with indexable CVD coated carbide insert. Analyses revealed that the variation in cutting speeded and feed did not significantly affect the surface roughness of the machined surface. Generally, the surfaces produced are very smooth with $R_{a}$ values in the range of $0.1-0.43 \mu \mathrm{m}$, and studies showed almost no microstructure alteration on the machined surfaces. However, at the highest cutting condition, i.e. a cutting speed of $160 \mathrm{~m} /$ $\mathrm{min}$, and feed of $0.02 \mathrm{~mm} /$ tooth, some compression and distortion effects were detected on the microstructure at the very shallow depth of approximately $2.2 \mu \mathrm{m}$ from the machined surface.

Keywords: Surface integrity, hardened tool steel, end-milling, microstructure, coated carbide tool

\subsection{PENGENALAN}

Bahagian-bahagian keluli terkeras digunakan secara meluas dalam industri automotif, gear, galas, perkakas dan acuan [1]. Untuk pemesinan penyudahan bahagian terkeras

Jabatan Kejuruteraan Mekanik dan Bahan, Universiti Kebangsaan Malaysia, 43600 UKM Bangi, Selangor. E-mail: chase@vlsi.eng.ukm.my 
ini, operasi larikan dan pengisaran menjadi kaedah utama pemesinan menggantikan proses pencanaian [2-3]. Pada masa ini, kaedah ini mampu memberikan pelbagai kelebihan, terutama sekali dalam mengurangkan kos dan menjimatkan masa pembuatan komponen berbanding rutin yang biasa. Sesuai dengan itu, penyudahan komponen yang diperbuat daripada bahan keluli terkeras menggunakan operasi pengisaran merupakan cabaran utama yang dihadapi dalam industri pembuatan acuan dan sektor automotif.

Kualiti penyudahan permukaan yang telah dimesin biasanya diteliti dalam bidang yang dikenali sebagai keutuhan permukaan. Keutuhan permukaan merupakan satu kajian yang menerangkan keadaan dan sifat permukaan sesuatu benda kerja setelah ianya dimesin. Ianya merangkumi kombinasi kompleks penyudahan permukaan seperti tegasan baki, kerja sejuk, transformasi fasa, kakisan dan mekanisme pergerakan serpihan [4]. Maklumat tentang keutuhan permukaan adalah merujuk kepada kajian tekstur, topografi, kekasaran, kekerasan dan mikrostruktur permukaan [5].

Perubahan subpermukaan yang mungkin dijana semasa proses pemesinan logam adalah seperti retak, tegasan baki, kekerasan mikro, penghabluran semula dan penjelmaan fasa. Perubahan ini mungkin cetek di permukaan atau mungkin juga dalam dan meluas pada lapisan permukaan, menjadikan sifat permukaan berbeza berbanding bahan pukal. Keutuhan permukaan yang terhasil semasa proses pemesinan harus dikawal dalam pembuatan komponen yang dikenakan tegasan yang tinggi, terutama sekali apabila aplikasinya melibatkan kos yang tinggi, kebolehpercayaan, hayat komponen yang boleh dijangka dan keselamatan pengguna. Dalam pengeluaran sesuatu komponen, didapati kos pemesinan adalah kos tertinggi berbanding kos lain seperti kos bahan dan rawatan haba. Oleh itu, prosedur dan keadaan pemesinan yang sesuai haruslah dikenalpasti untuk mencapai keutuhan permukaan yang optimum.

Ramai penyelidik sebelum ini [6-8] menyatakan bahawa keutuhan permukaan yang dihasilkan oleh pelbagai proses pemesinan sangat mempengaruhi prestasi lesu komponen. Kegagalan lesu komponen dinamik secara rawak bermula pada atau berhampiran dengan permukaan komponen dan sangat bergantung kepada keadaan permukaan tersebut. Hayat lesu sesuatu komponen tersebut bergantung kepada tegasan baki pada permukaan benda kerja yang telah dimesin. Tegasan baki ini kebiasaannya wujud bersama-sama lapisan putih tipis yang boleh dilihat pada sesetengah permukaan keluli yang telah dimesin. Dari aspek perubahan metalurgi, haba yang terjana semasa pemotongan adalah sumber utama perubahan permukaan ini [9].

Kajian pemesinan ke atas keluli terkeras telah pun dilakukan oleh beberapa penyelidik terdahulu [3, 10-12] yang melibatkan operasi larikan dan pengisaran. Dalam kajian ini pula, perkakas karbida bersalut digunakan untuk memesin keluli perkakas terkeras secara pengisaran hujung. Matlamat umum penyelidikan ini adalah untuk menentukan kesan keadaan pemotongan yang berbeza terhadap kemasan permukaan keluli yang telah dimesin. 


\subsection{BAHAN DAN METODOLOGI}

\subsection{Perkakas Pemotong dan Bahan Benda Kerja}

Perkakas pemotong tungsten karbida bersalut gred T25M dengan piawaian ISO XOX 120408TR-D14 digunakan dalam ujikaji ini. Perkakas pemotong dipasang dengan tegar pada pemegang perkakas pengisaran hujung (piawaian ISO R217.692020.3-12-2A) yang berdiameter $20 \mathrm{~mm}$ dan mempunyai dua pinggir pemotongan (dua sisip). Geometri perkakas pemotong diberi dalam Jadual 1.

Jadual 1 Geometri perkakas pemotong

\begin{tabular}{ll}
\hline Lebar serongan (mm) & 0.16 \\
Sudut serongan & $14^{\circ}$ \\
Sudut potongan sadak & $1^{\circ}$ \\
Sudut paksi sadak & $8^{\circ}$ \\
Sudut jejarian sadak & $-7^{\circ}$ \\
Sudut lega permukaan & $7^{\circ}$ \\
Sudut lega persisian & $7^{\circ}$ \\
Sudut permukaan pinggir potongan & $17^{\circ}$ \\
Sudut persisian pinggir potongan & $0^{\circ}$ \\
Sudut kelegaan permukaan & $15^{\circ}$ \\
Sudut kelegaan persisian & $1^{\circ}-15^{\circ}$ \\
Sudut penentuan bilah & $90^{\circ} 8^{\prime}$ \\
Sudut heliks & $15^{\circ}$ \\
\hline
\end{tabular}

Sumber: Pembekal perkakas pemotong

Bahan benda kerja yang digunakan adalah keluli perkakas kerja sejuk AISI D2 yang telah dikeraskan sepenuhnya kepada $62 \mathrm{HRC}$. Komposisi kimia AISI D2 yang dibekalkan ialah (dalam peratus berat) C 1.42\%, Si 0.3\%, Mn 0.4\%, Cr 11.2\%, Mo 0.8\% dan V 0.2\%. Sifat fizikal bahan benda kerja pula ditunjukkan dalam Jadual 2. Bahan ini diterima dalam bentuk bar segiempat dengan dimensi $305 \mathrm{~mm} \times 70 \mathrm{~mm} \times$ $53 \mathrm{~mm}$.

Jadual 2 Sifat fizikal keluli perkakas (pada suhu bilik)

\begin{tabular}{ll}
\hline Ketumpatan $\left(\mathrm{kg} / \mathrm{m}^{3}\right)$ & 7700 \\
Modulus kekenyalan $\mathrm{N} / \mathrm{mm}^{2}$ & 193000 \\
Kekonduksian terma $\left(\mathrm{W} / \mathrm{m}^{\circ} \mathrm{C}\right)$ & 20.2 \\
Kekerasan $(\mathrm{HRc})$ & $60-62$ \\
Haba tentu $\left(\mathrm{J} / \mathrm{kg}^{\circ} \mathrm{C}\right)$ & 460 \\
\hline
\end{tabular}




\subsection{Keadaan Pemesinan}

Ujikaji pengisaran dilakukan menggunakan mesin pengisar tegak kawalan berkomputer (CNC) Cincinnati Sabre 750 tanpa bendalir pemotongan. Kebiasaannya, pengisaran acuan kerap kali dilakukan secara kering dalam mesin pengisaran yang terbuka. Selain menjimatkan kos pengeluaran, penggunaan bendalir pemotongan boleh memberikan kesan terhadap keutuhan permukaan. Penggunaan bendalir pemotongan dalam operasi pengisaran hujung perlu dielakkan kerana ianya meningkatkan kecenderungan berlakunya permulaan retak di bawah permukaan [2].

(a)

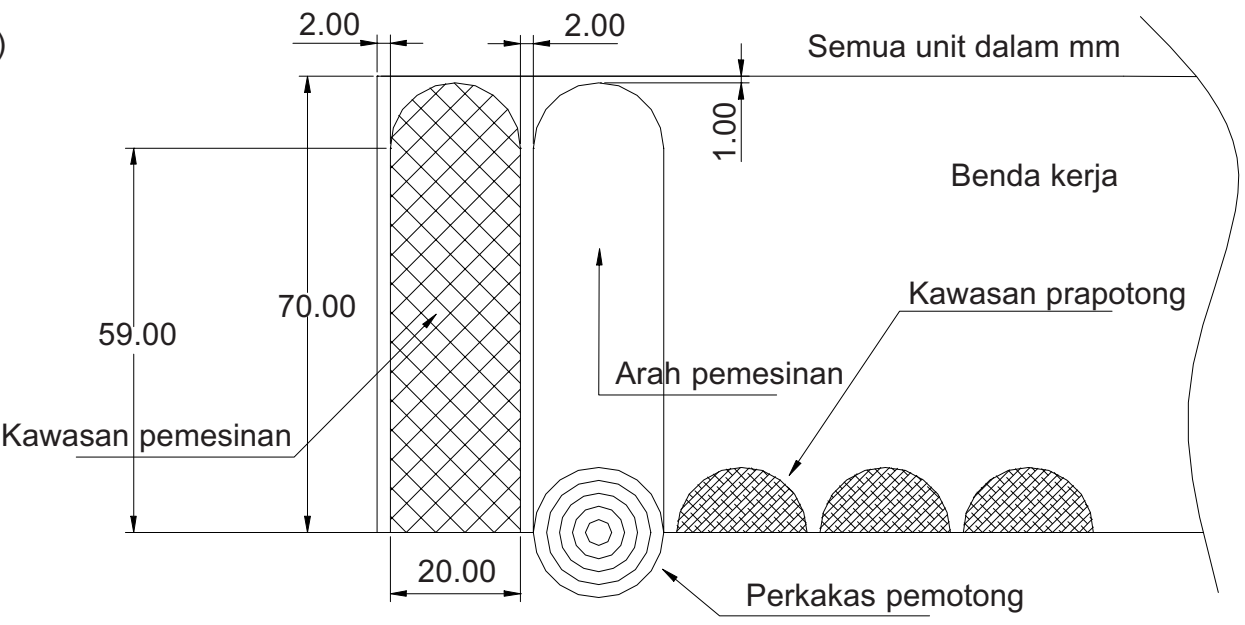

(b)

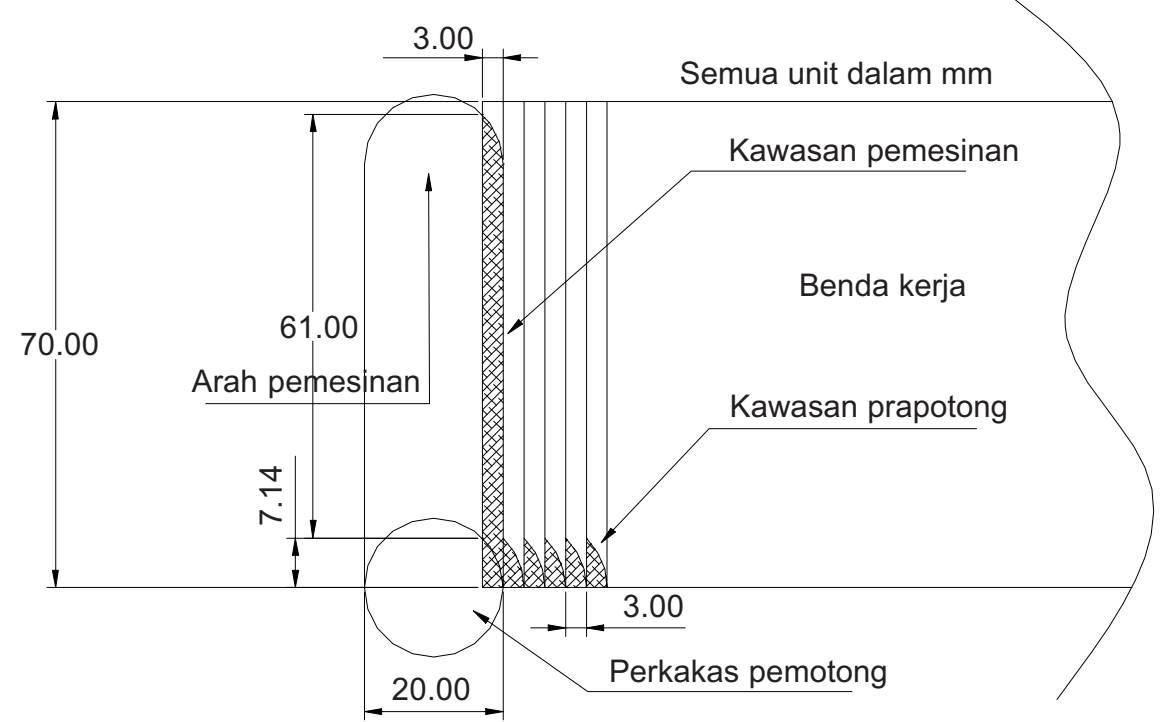

Rajah 1 Gambar rajah skema (a) pengisaran masukan penuh (100\%) dan (b) pengisaran masukan $15 \%$. 
Merujuk kepada kedudukan pemotongan, dua keadaan pengisaran dilakukan iaitu pengisaran masukan penuh dan pengisaran masukan 15\% (Rajah 1). Bagi pengisaran masukan penuh, kelajuan pemotongan yang digunakan adalah 50, 65, 72, 80 dan $95 \mathrm{~m} / \mathrm{min}$, manakala kedalaman pemotongan paksian dikekalkan pada 1 mm bagi kesemua kelajuan pemotongan. Bagi pengisaran masukan 15\% pula, kelajuan pemotongan yang digunakan adalah 80, 100, 120, 140 dan $160 \mathrm{~m} / \mathrm{min}$, manakala kedalaman pemotongan paksian dikekalkan pada $3 \mathrm{~mm}$ bagi kesemua kelajuan pemotongan. Suapan per putaran $\left(f_{z}\right)$ yang digunakan bagi kedua-dua keadaan adalah 0.01 dan $0.02 \mathrm{~mm} /$ sisip. Pemesinan bagi setiap set keadaan pemotongan diulangi sebanyak tiga kali supaya keputusan yang lebih tepat diperolehi. Setiap ujian dimulakan dengan pinggir pemotongan yang baru dan operasi pengisaran diberhentikan apabila haus rusuk sisip melampaui $0.3 \mathrm{~mm}$. Haus rusuk digunakan sebagai had rujukan kerana kajian ini adalah sebahagian daripada kajian ke atas haus perkakas karbida bersalut dalam pengisaran keluli perkakas [13].

\subsection{Pengukuran Kekasaran Permukaan}

Nilai kekasaran permukaan, $R_{a}[14]$ diukur menggunakan meter profil permukaan (Mitutoyo Surftest 420). Bacaan diambil sekurang-kurangnya tiga kali pada tiga tempat yang berlainan dengan pergerakan lurus hujung stylus dalam arah yang selari dengan arah gerakan suapan pada pelbagai sela pemotongan bagi kesemua keadaan pemotongan.

\subsection{Analisis Mikrostruktur}

Untuk mendapatkan sampel permukaan yang dimesin, bahan benda kerja dipotong pada saiz dan bentuk tertentu menggunakan gergaji besi biasa. Ini dilakukan pada keadaan yang lembut dan berhati-hati bagi mengelakkan sebarang perubahan mikrostruktur sampel. Sampel dicagak dalam acuan menggunakan serbuk cagakan termoset konduktif. Sampel yang telah dicagak kemudiannya dicanai dan digilap untuk mendapatkan permukaan yang licin menggunakan bahan pelelas berlian pada saiz yang berbeza-beza. Sampel tersebut kemudiannya dipunar menggunakan nital sebelum diperhatikan di bawah mikroskop imbasan laser (Leica Confocal ICM1000).

\subsection{KEPUTUSAN DAN PERBINCANGAN}

\subsection{Kekasaran Permukaan}

Rajah 2 dan Rajah 3 memaparkan kesan halaju pemesinan dengan masukan penuh terhadap kekasaran permukaan yang dimesin pada masa pemotongan yang berbeza. Rajah 2 khusus untuk $f_{z}=0.01 \mathrm{~mm} / \mathrm{sisip}$, sementara Rajah 3 adalah untuk keadaan pemesinan $f_{z}=0.02 \mathrm{~mm} / \mathrm{sisip}$. Ini diikuti oleh Rajah 4 dan Rajah 5 yang juga 
memaparkan kesan halaju pemesinan terhadap kekasaran permukaan yang dimesin pada masa pemotongan yang berbeza, tetapi pada masukan $15 \%$. Rajah 4 adalah untuk keadaan pemesinan $f_{z}=0.01 \mathrm{~mm} / \mathrm{sisip}$, sementara Rajah 5 untuk $f_{z}=0.02$ $\mathrm{mm} / \mathrm{sisip}$.

Berdasarkan Rajah 2 dan Rajah 3, didapati bahawa nilai-nilai $R_{a}$ tertumpu pada suatu julat yang sempit dan banyak berlaku pertindihan bagi lengkung nilai $R_{a}$ ini

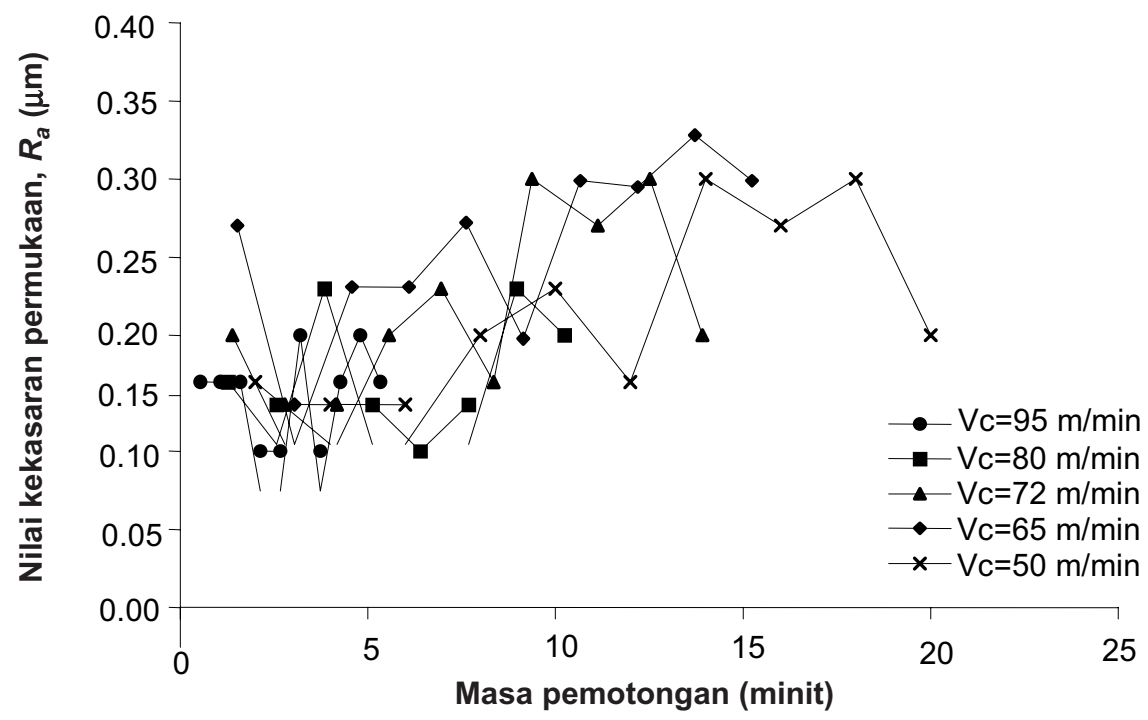

Rajah 2 Graf nilai kekasaran permukaan, $R_{a}$ melawan masa pemotongan pada suapan, $f_{z}=0.01$ $\mathrm{mm} / \mathrm{sisip}$ (masukan penuh)

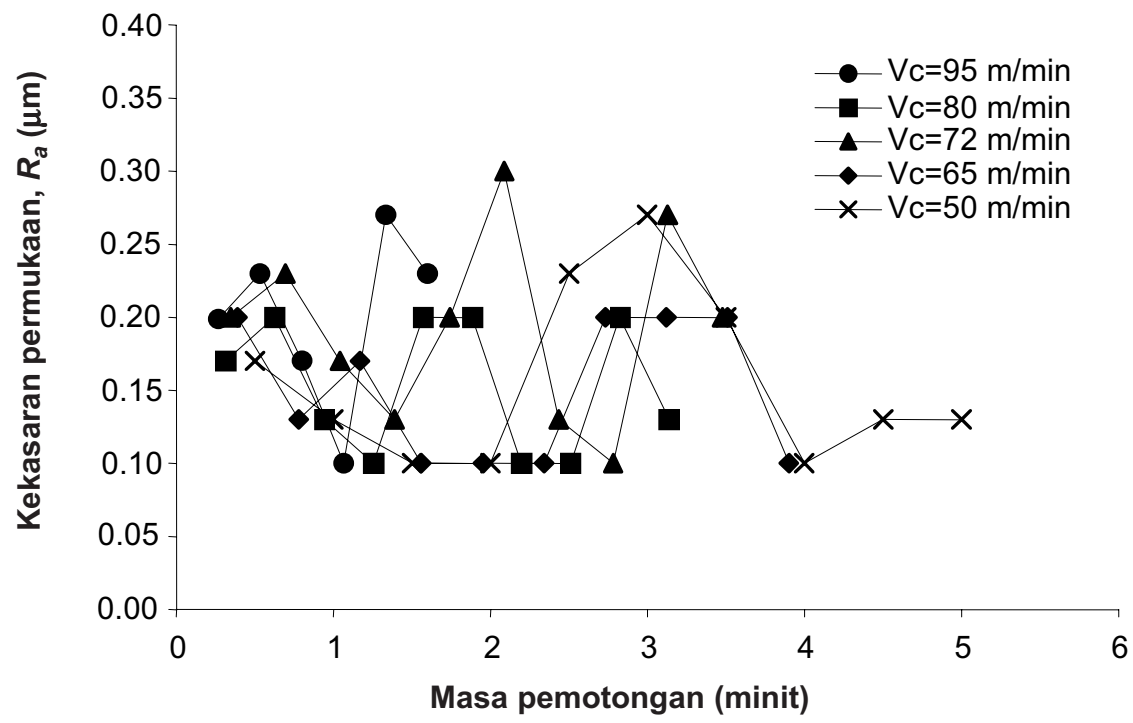

Rajah 3 Graf nilai kekasaran permukaan, $R_{a}$ melawan masa pemotongan pada suapan, $f_{z}=0.02$ $\mathrm{mm} / \mathrm{sisip}$ (masukan penuh) 
pada kelajuan pemotongan yang berbeza-beza. Ini menunjukkan bahawa tiada hubungan yang jelas antara nilai $R_{a}$ dan kelajuan pemotongan sepanjang proses pemotongan dilakukan. Walau bagaimanapun, dapat diperhatikan bahawa bagi suapan $0.01 \mathrm{~mm} / \mathrm{sisip}$, kelajuan pemotongan yang lebih tinggi menghasilkan permukaan yang lebih licin. Nilai $R_{a}$ terendah iaitu $0.1 \mu \mathrm{m}$ kerap diperolehi pada kelajuan pemotongan tertinggi iaitu $95 \mathrm{~m} / \mathrm{min}$. Didapati berlaku kenaikan nilai $R_{a}$ berhubung dengan masa pemotongan tetapi nilai tersebut semakin stabil pada peningkatan kelajuan pemotongan. Keadaan ini berbeza berbanding suapan 0.02 $\mathrm{mm} / \mathrm{sisip}$. Kesemua kelajuan pemotongan mencatatkan nilai $R_{a}$ yang hampir sama pada suatu julat nilai $R_{a}$ dan tiada sebarang kecenderungan peningkatan nilai $R_{a}$ ini. Pertindihan lengkung bagi kesemua kelajuan pemotongan adalah lebih ketara sama ada pada awal, pertengahan atau akhir pemotongan, menunjukkan bahawa tiada hubungan yang jelas antara nilai $R_{a}$ dan kelajuan pemotongan. Umumnya, permukaan yang dihasilkan adalah sangat licin dengan $R_{a}$ berada pada nilai $0.1 \mu \mathrm{m}$ hingga $0.37 \mu \mathrm{m}$.

Melihat pada Rajah 4 dan Rajah 5, didapati bahawa keadaan yang sama seperti dalam kes pengisaran masukan penuh diperolehi, di mana nilai $R_{a}$ tertumpu pada suatu julat yang sempit. Keseluruhan lengkung bagi setiap kelajuan pemotongan bertindih antara satu sama lain sama ada pada awal, pertengahan atau pada akhir pemotongan, menunjukkan tiada hubungan yang jelas antara nilai $R_{a}$ dan kelajuan pemotongan sepanjang pemotongan berlangsung. Nilai $R_{a}$ berayun pada julat yang mendatar, yang mana nilai $R_{a}$ pada akhir pemotongan masih sama sepertimana

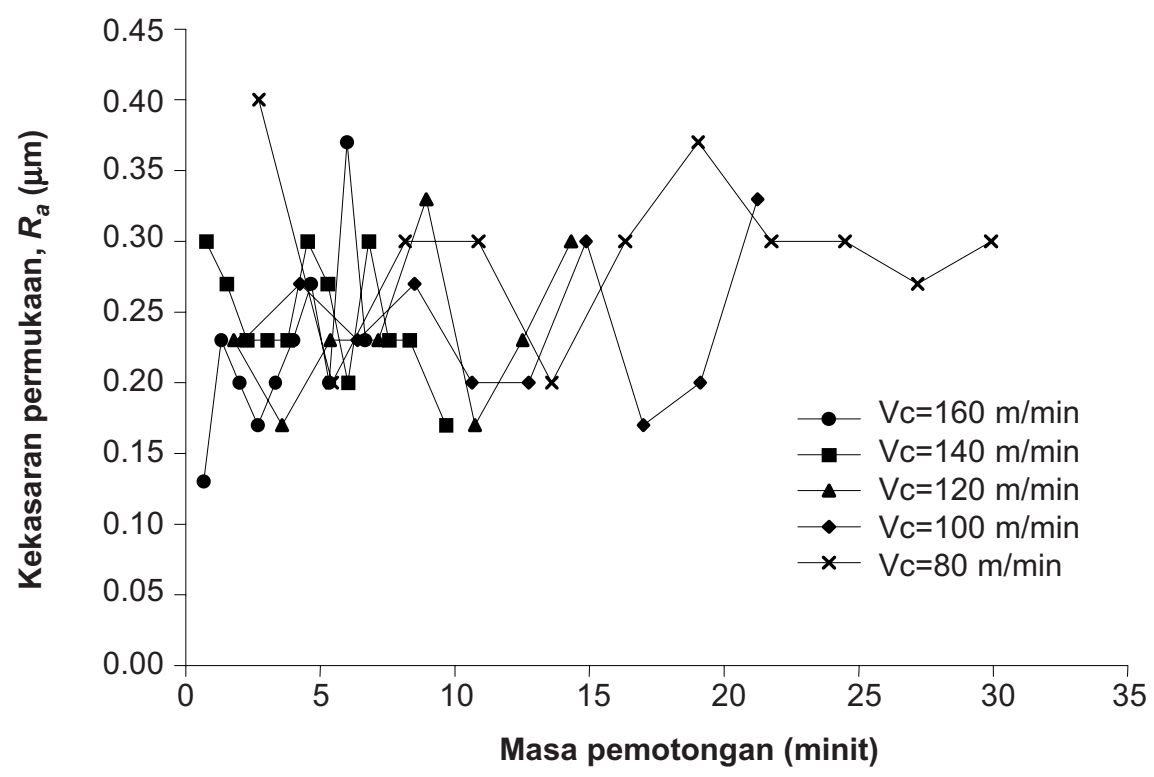

Rajah 4 Graf nilai kekasaran permukaan, $R_{a}$ melawan masa pemotongan pada suapan, $f_{z}=0.01$ $\mathrm{mm} / \mathrm{sisip}$ (masukan 15\%) 


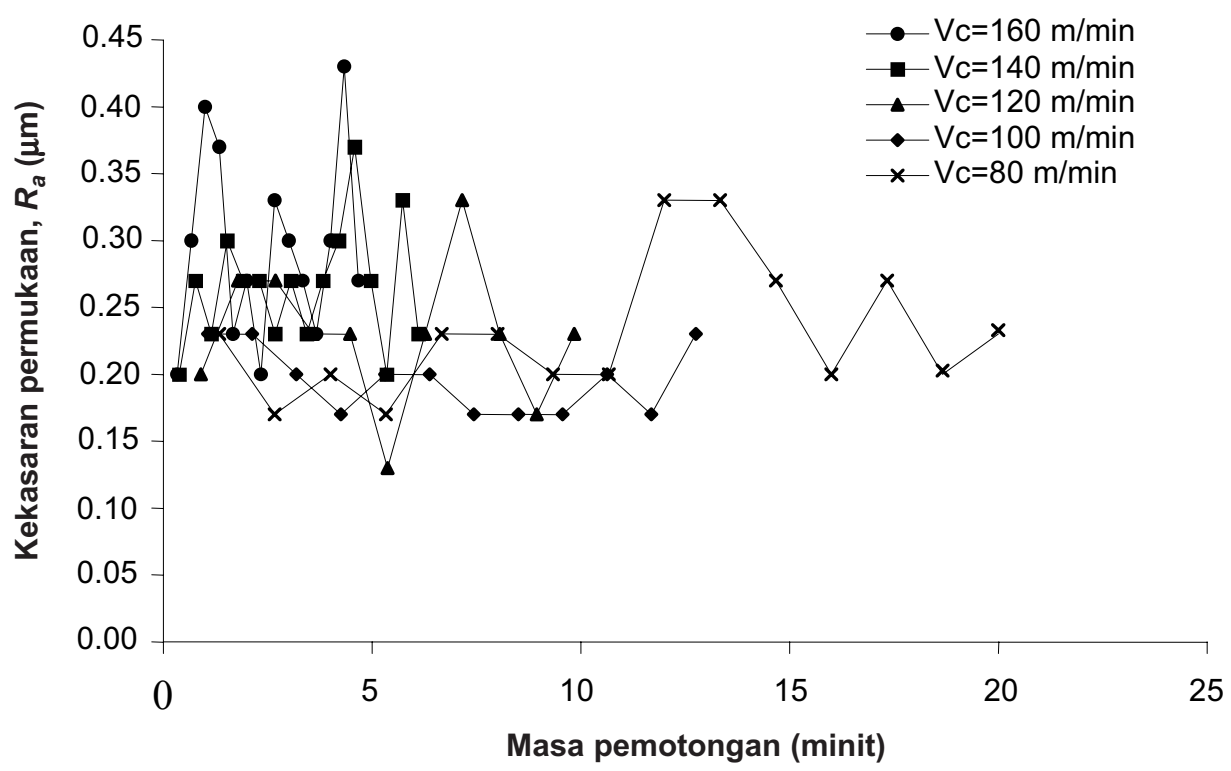

Rajah 5 Graf nilai kekasaran permukaan, $R_{a}$ melawan masa pemotongan pada suapan, $f_{z}=0.02$ mm/sisip (masukan 15\%)

yang diperolehi di awal pemotongan. Akan tetapi, jika dilihat pada kelajuan pemotongan tertinggi bagi suapan $0.01 \mathrm{~mm} / \mathrm{sisip}$, nilai $R_{a}$ yang diperolehi adalah lebih rendah secara relatif berbanding nilai $R_{a}$ yang diperolehi pada kelajuan pemotongan lain yang lebih rendah. Keadaan ini berbeza berbanding pada suapan $0.02 \mathrm{~mm} / \mathrm{sisip}$ yang mana kelajuan pemotongan tertinggi mencatatkan nilai $R_{a}$ yang lebih tinggi berbanding nilai $R_{a}$ yang dicatat pada kelajuan pemotongan yang lebih rendah.

Keadaan yang sama pernah dialami oleh Axinte dan Dewes [15]. Keadaan ini sebenarnya bercanggah dengan jangkaan biasa iaitu kelajuan pemotongan yang lebih tinggi umumnya memberikan kekasaran permukaan yang lebih rendah disebabkan oleh tiada kesan pinggir terbina. Walau bagaimanapun, Axinte dan Dewes [15] mengaitkan keadaan ini dengan ketidakseimbangan perkakas pada kelajuan pemotongan yang tinggi. Dalam kajian ini, pinggir pemotongan mungkin tidak dapat bertahan lagi disebabkan oleh beban serpihan yang lebih tinggi. Di samping itu, kelajuan pemotongan yang tinggi menyebabkan suhu yang lebih tinggi terjana, menjadikan penyerpihan kecil kerap berlaku.

Getaran antara perkakas dan permukaan benda kerja boleh juga dikaitkan dalam kes ini disebabkan oleh beban dinamik pemotongan hasil daripada suapan dan kelajuan pemotongan yang lebih tinggi. Keadaan ini berbeza berbanding dalam kes suapan $0.01 \mathrm{~mm} / \mathrm{sisip}$ di mana kelajuan pemotongan yang lebih tinggi dapat membantu menghasilkan permukaan yang lebih licin disebabkan ketiadaan pinggir terbina [13]. Pinggir terbina hanya cenderung untuk terbentuk pada julat kelajuan 
pemotongan tertentu. Jika kelajuan pemotongan yang lebih tinggi di luar julat ini digunakan, pembentukan pinggir terbina dapat dilenyapkan dan permukaan yang lebih licin akan diperolehi [11]. Dalam kes ini, kelajuan pemotongan $160 \mathrm{~m} / \mathrm{min}$ adalah cukup tinggi untuk melenyapkan pembentukan pinggir terbina, di samping suapan yang lebih rendah untuk menjana permukaan yang lebih baik.

\subsection{Metalurgi Permukaan}

Umumnya, dalam ujikaji ini didapati tiada lapisan putih atau lapisan gelap atau sebarang perubahan mikrostruktur lain seperti ubah bentuk plastik dapat dikesan di bawah permukaan yang dimesin berdasarkan sampel yang diperhatikan di bawah mikroskop, walaupun pada faktor pembesaran yang tinggi. Ini dapat dilihat pada mikrostruktur keratan rentas permukaan yang telah dimesin seperti yang ditunjukkan pada Rajah 6 hingga Rajah 8. Walau bagaimanapun, apabila diperhatikan pada Rajah 9 yang menunjukkan mikrostruktur permukaan yang diambil pada kelajuan pemotongan tertinggi $(160 \mathrm{~m} / \mathrm{min})$ dan suapan yang lebih tinggi $(0.02 \mathrm{~mm} / \mathrm{sisip})$, didapati bahawa berlaku sedikit gangguan pada mikrostruktur permukaan. Dapat dilihat bahawa mikrostruktur yang termampat dan terherot, dan ditunjukkan oleh ira-ira pada kedalaman yang sangat cetek iaitu lebih kurang $2.2 \mu \mathrm{m}$ sahaja dari permukaan termesin.

Gangguan kecil yang berlaku pada keadaan pemotongan tertinggi ini adalah disebabkan oleh tindakan haba yang tinggi secara relatif telah melembutkan permukaan ini, seterusnya daya pemotongan pada sisip pula menekan mikrostruktur

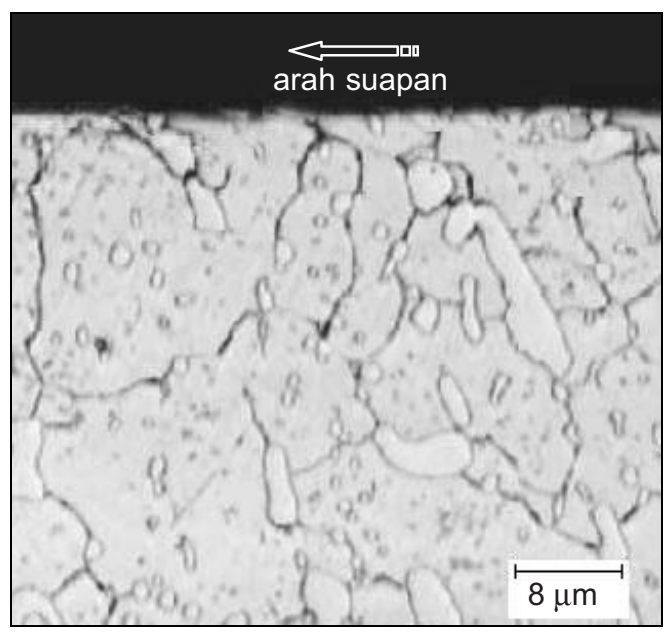

Rajah 6 Struktur mikro permukaan termesin pada pengisaran hujung masukan penuh. Keadaan pemotongan: $V_{c}=95 \mathrm{~m} / \mathrm{min} ; f_{z}=0.01$ $\mathrm{mm} / \mathrm{sisip}$

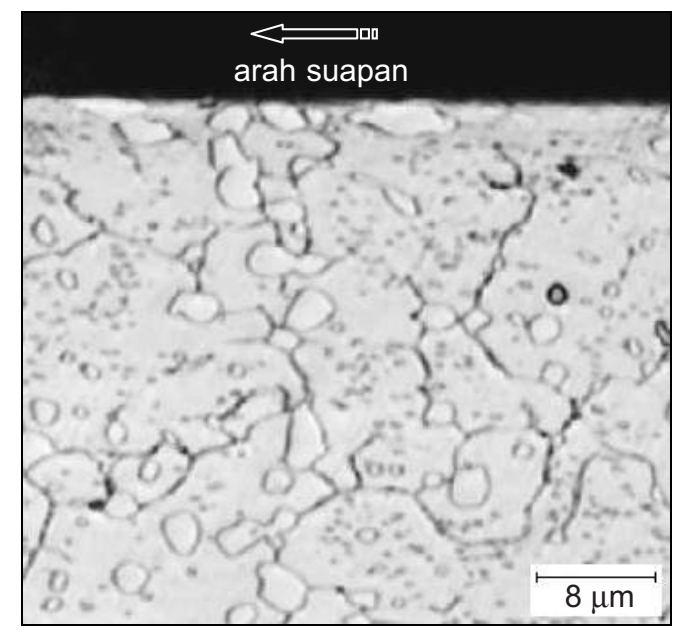

Rajah 7 Struktur mikro permukaan termesin pada pengisaran hujung masukan penuh. Keadaan pemotongan: $V_{c}=95 \mathrm{~m} / \mathrm{min} ; f_{z}=0.02$ $\mathrm{mm} / \mathrm{sisip}$ 


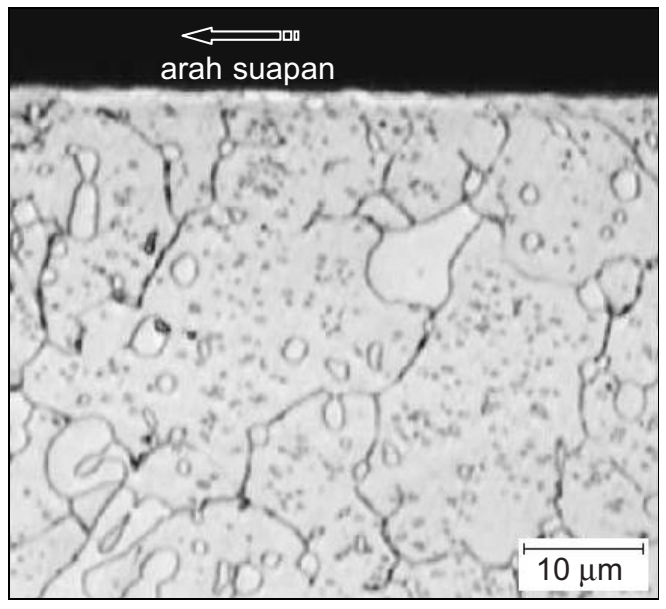

Rajah 8 Struktur mikro permukaan termesin pada pengisaran hujung masukan $15 \%$. Keadaan pemotongan: $V_{c}=160 \mathrm{~m} / \mathrm{min} ; f_{z}=0.01 \mathrm{~mm} / \mathrm{sisip}$

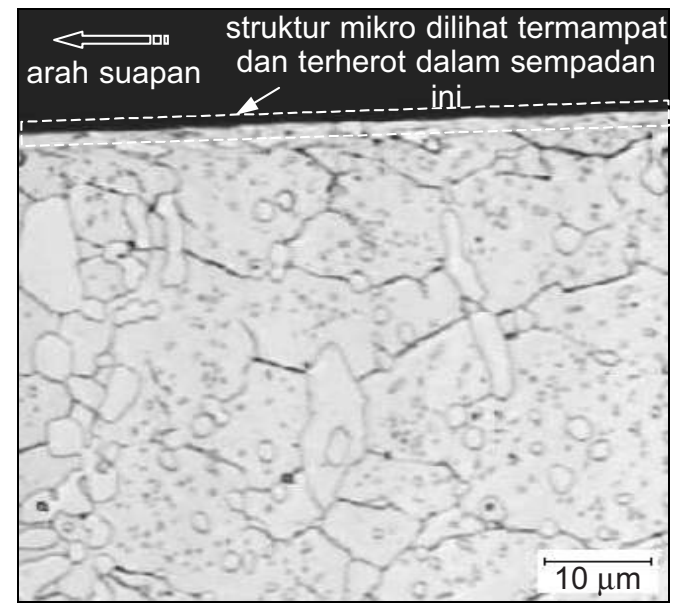

Rajah 9 Struktur mikro permukaan termesin pada pengisaran hujung masukan $15 \%$. Keadaan pemotongan: $V_{c}=160 \mathrm{~m} / \mathrm{min} ; f_{z}=0.02 \mathrm{~mm} / \mathrm{sisip}$

dan menolaknya ke arah pergerakan suapan atau arah pemotongan. Selain daripada tindakan haba dan daya pemotongan yang lebih tinggi pada keadaan ini, tekanan dan penolakan terhadap mikrostruktur juga disebabkan oleh geseran dan penggosokan yang lebih kuat pada keadaan ini antara pinggir perkakas yang telah tumpul pada akhir pemotongan dan permukaan benda kerja.

Daripada pemerhatian ke atas struktur mikro ini, dapat disimpulkan bahawa pengisaran hujung ke atas keluli perkakas AISI D2 yang dilakukan secara kering dalam julat kelajuan pemotongan dan suapan yang digunakan hanya memberikan gangguan yang sangat minimum terhadap mikrostruktur dan hanya berlaku pada keadaan pemotongan maksimum. Satu-satunya alasan mengapa ujikaji ini dapat mengekalkan keutuhan permukaan bahan benda kerja adalah suhu pemotongan dan haba yang terjana tidak mencukupi untuk mengakibatkan perubahan mikrostruktur sepertimana yang diperolehi oleh penyelidik seperti Dewes et al. [3], Mantle dan Aspinwall [16] serta Barbacki dan Kawalec [17].

Dalam ujikaji ini, adalah dijangkakan bahawa suhu pemotongan maksimum yang dicapai adalah sentiasa lebih rendah berbanding suhu pembajaan keluli perkakas yang digunakan. Dewes et al. [3] yang memotong keluli perkakas AISI H13 (52 $\mathrm{HRC)}$ menggunakan operasi pengisaran kelajuan tinggi mendapati bahawa suhu pemotongan adalah di bawah $400^{\circ} \mathrm{C}$ dan mereka menjangkakan masalah keutuhan permukaan dapat diminimumkan kerana suhu yang terjana tidak melepasi suhu pembajaan AISI $\mathrm{H} 13$ iaitu $500^{\circ} \mathrm{C}$. Menurut pembekal bahan benda kerja, suhu pembajaan keluli AISI D2 yang dibekalkan untuk kajian ini adalah $520^{\circ} \mathrm{C}$. Maka perkara yang sama seperti Dewes et al. [3] dijangkakan berlaku dalam ujikaji ini. Hipotesis ini juga disokong oleh kajian Mantle dan Aspinwall [16]. 
Dalam kajian ini, tiada perubahan yang jelas pada mikrostruktur dalam operasi pengisaran keluli perkakas terkeras. Tiada kewujudan lapisan putih atau perubahan/ kemerosotan yang ketara berlaku pada mikrostruktur permukaan termesin. Ini selaras dengan kajian keutuhan permukaan oleh Axinte dan Dewes [15] bagi keluli perkakas mereka dan kajian Jacobson [18] dalam operasi melarik keras benda kerja M50.

Terdapat dua alasan berlakunya keadaan ini di mana proses pemesinan yang dilalui oleh keluli terkeras ini tidak memberikan sebarang kesan buruk terhadap penyudahan permukaan daripada sudut mikrostruktur. Sebab dan alasan ini tertumpu pada suhu pemotongan dan haba yang terjana sepertimana yang telah dinyatakan sebelum ini. Alasan pertama melibatkan parameter pemotongan. Menurut Trent [19], suhu pemotongan adalah berkait rapat dengan kelajuan pemotongan di mana semakin tinggi kelajuan pemotongan, suhu pemotongan juga semakin meningkat. Ujikaji pemesinan yang dilakukan ini dipertimbangkan sebagai berada pada tahap kelajuan rendah atau sederhana dengan julat kelajuan pemotongan $50 \mathrm{~m} / \mathrm{min}$ hingga $160 \mathrm{~m} / \mathrm{min}$. Oleh itu, suhu pemotongan juga adalah tidak terlampau tinggi sepanjang ujikaji dan keadaan yang sebaliknya akan berlaku jika kelajuan pemotongan yang lebih tinggi digunakan [3], di mana suhu pemotongan meningkat dengan peningkatan kelajuan pemotongan kepada suhu maksimum yang menyamai takat lebur bahan benda kerja dan tiada penurunan suhu berlaku pada kelajuan pemotongan yang lebih tinggi. Pada suhu maksimum ini, penjelmaan fasa mikrostruktur mungkin akan berlaku menyebabkan terbentuknya lapisan putih. Lapisan putih tersebut adalah hasil daripada perubahan mikrostruktur apabila bahan mencapai suhu kritikal iaitu suhu penjelmaan fasa dan diikuti dengan sepuhlindap-sendiri yang pantas [20].

Alasan kedua melibatkan agihan haba yang terjana dalam zon pemotongan. Mikrostruktur benda kerja yang tidak mengalami gangguan dan perubahan dalam ujikaji ini adalah disebabkan oleh hanya sebahagian kecil haba yang dipindahkan kepada bahan benda kerja menyebabkan suhu yang dicapai olehnya adalah rendah secara relatif berbanding suhu pemotongan. Sejumlah besar haba pemotongan dipindahkan kepada serpihan [21]. Menurut Barbacki dan Kawalec [17] pula, kekonduksian haba yang rendah bagi bahan benda kerja juga mungkin akan menghad haba daripada dipindahkan kepada bahan semasa pemotongan, sebaliknya sebahagian besar haba ini dipindahkan kepada serpihan dan dibuang dari pemotongan.

Daripada pemerhatian yang dibuat ke atas serpihan, didapati bahawa sebahagian besar serpihan ini berwarna biru kehitaman dan hanya sedikit warna keemasan yang sangat gelap di tepi serpihan. Warna biru gelap atau kehitaman menunjukkan suhu serpihan yang lebih tinggi berbanding permukaan benda kerja [13]. Ini bermakna sejumlah besar haba telah dipindahkan kepada serpihan. Dalam kajian ini didapati bahawa semakin tinggi kelajuan pemotongan dan suapan, warna serpihan yang dihasilkan semakin gelap, menggambarkan takat pengoksidaan yang lebih tinggi hasil dari suhu serpihan yang lebih tinggi. Jelaslah bahawa sebahagian besar haba dipindahkan kepada serpihan yang dibuang, sebaliknya hanya sebahagian 
kecil haba yang dipindahkan kepada permukaan benda kerja, maka sebarang perubahan mikrostruktur hasil daripada haba yang terjana dalam pemesinan tidak berlaku.

\subsection{KESIMPULAN}

Kajian ini mendapati bahawa peningkatan kelajuan pemotongan dalam julat 50 $\mathrm{mm} / \mathrm{min}$ hingga $95 \mathrm{~m} / \mathrm{min}$ bagi pengisaran hujung masukan penuh dan $80 \mathrm{~m} / \mathrm{min}$ hingga $160 \mathrm{~m} / \mathrm{min}$ bagi pengisaran hujung masukan 15\% tidak menunjukkan pengaruh yang jelas terhadap variasi nilai kekasaran permukaan yang dihasilkan. Perubahan suapan daripada $0.01 \mathrm{~mm} / \mathrm{sisip}$ kepada $0.02 \mathrm{~mm} / \mathrm{sisip}$ juga memberi kesan yang sama. Pada kesemua keadaan pemotongan, nilai kekasaran permukaan hanya berayun dalam suatu julat nilai yang sempit. Permukaan yang dijana pada keseluruhan ujikaji adalah sangat licin dengan nilai kekasaran purata, $R_{a}$ berada dalam julat 0.10 $\mu \mathrm{m}-0.43 \mu \mathrm{m}$. Pengisaran hujung masukan penuh menjana permukaan yang lebih licin dengan nilai $R_{a}$ berada dalam julat $0.10 \mathrm{~mm}-0.37 \mathrm{~mm}$ berbanding pengisaran hujung masukan $15 \%$ di mana nilai-nilai $R_{a}$ yang diperolehi berada dalam julat yang lebih tinggi iaitu $0.13 \mu \mathrm{m}-0.43 \mu \mathrm{m}$.

Selain daripada itu, kajian ini juga mendapati sampel permukaan termesin menunjukkan hanya berlaku gangguan mikrostruktur yang sangat kecil pada permukaan termesin. Ini kerana suhu yang dicapai oleh permukaan benda kerja adalah rendah secara relatif, di samping kelajuan pemotongan dan suapan yang rendah digunakan.

\section{PENGHARGAAN}

Penulis ingin merakamkan setinggi-tinggi penghargaan kepada Universiti Kebangsaan Malaysia yang telah membiayai penyelidikan ini melalui peruntukan FK 0010/99.

\section{RUJUKAN}

[1] Poulachon, G., B. P. Bandyopadhyay, I. S. Jawahir, S. Pheulpin, dan E. Seguin. 2003. The Influence of the Microstructure of Hardened Tool Steel Workpiece on the Wear of PCBN Cutting Tools. Int. J. of Machine Tools \& Manufacture. 43: 139-144.

[2] Braghini Jr, A., dan R. T. Coelho. 2001. An Investigation of the Wear Mechanisms of Polycrystalline Cubic Boron Nitride (PCBN) Tools When End Milling Hardened Steels at Low/Medium Cutting Speeds. Int. J. Adv. Manuf. Technol. 17: 244-257.

[3] Dewes, R. C., E. Ng, K. S. Chua, P. G. Newton, dan D. K. Aspinwall. 1999. Temperature Measurement When High Speed Machining Hardened Mould/Die Steel. J. of Materials Proc. Techn. 92-93: 293-301.

[4] Li X. S., dan I. M. Low. 1994. Evaluation of Advanced Alumina-Based Ceramic Tool Inserts When Machining High Tensile-Steel. Journal Of Material Science. 29: 3121-3127.

[5] Field, M., dan J. F. Kahles. 1971. Review of Surface Integrity of Machined Components. Annals of The CIRP. 20(2): 153-163.

[6] Sharman, A. R. C., D. K. Aspinwall, R. C. Dewes, D. Clifton, dan P. Bowen. 2001. The Effects of Machined Workpiece Surface Integrity on the Fatigue Life of G-Titanium Aluminide. Int. J. of Machine Tools \& Manufacture. 41: 1681-1685. 
[7] Thiele,J. D., dan S. N. Melkote. 2000. Effect of Tool Edge Geometry on Workpiece Subsurface Deformation and Through-thickness Residual Stress for Hard Turning of AISI 52100 Steel. J. of Manufacturing Processes, SME. 2(4): 270-276.

[8] Watson, D. W., dan M. C. Murphy. 1979. The Effect of Machining on Surface Integrity. The Metal and Materials Technology. 199-204.

[9] Abrao, A. M., M. L. H. Wise, dan D. K. Aspinwall. 1995. Tool Life and Workpiece Surface Integrity Evaluations When Machining Hardened AISI H13 and E52100 Steels with Conventional Ceramic and PCBN Tool Materials. SME Technical Paper No. MR 95-159.

[10] Sood, R., C. Guo, dan S. Malkin. 2000. Turning of Hardened Steels. J. of Manufacturing Processes, SME. 2(3): 187-193.

[11] Wuyi C. 2000. Cutting Forces and Surface Finish When Machining Medium Hardness Steel Using CBN Tools. Int. J. of Machine Tools \& Manufacture. 40: 455-466.

[12] Becze, C. E., P. Clayton, L. Chen, T. I. El-Wardany, dan M. A. Elbestawi. 2000. High-Speed Five-axis Milling of Hardened Tool Steel. Int. J. of Machine Tools E Manufacture. 40: 869-885.

[13] Goh, J. H. 2002. Prestasi Perkakas Pemotong Karbida Pelbagai Lapisan Salutan CVD dalam Pengisaran Kering Keluli Perkakas Terkeras. Tesis M. Sc. UKM. Bangi.

[14] ISO 468. 1982. Surface Roughness-Parameters, Their Values, and General Rules for Specifying Requirement.

[15] Axinte, D. A., dan R. C. Dewes. 2002. Surface Integrity of Hot Work Tool Steel after High Speed MillingExperimental Data and Empirical Models. J. of Materials Proc. Techn. 6010: 1-10.

[16] Mantle, A. L., dan D. K. Aspinwall. 2001. Surface Integrity of a High Speed Milled Gamma Titanium Aluminide. J. of Materials Proc. Techn. 118: 143-150.

[17] Barbacki, A., dan M. Kawalec. 1997. Structural Alterations in the Surface Layer During Hard Machining. J. of Materials Proc. Techn. 64: 33-39.

[18] Jacobson., M. 2002. Surface Integrity of Hard-turned M50 Steel. Proc. of the Institution of Mechanical Engineers, Part B: J. of Engg. Manufacture. 216(1): 47-54.

[19] Trent, E. M. 1995. Pemotongan Logam. Terj. Abu Abdullah. Kuala Lumpur: Dewan Bahasa dan Pustaka.

[20] Chou, Y. K., dan C. J. Evans. 1998. Process Effects on White Layer Formation in Hard Turning. Transactions of NAMRI/SME. 26: 117-122.

[21] Ning, Y., M. Rahman, dan Y. S. Wong. 2001. Investigation of Chip Formation in High Speed End Milling. J. of Materials Proc. Techn. 113: 360-367. 